\title{
SURINAAMSCHE GRENSKWESTIES HET EINDE IN ZICHT?
}

\author{
DOOR
}

\author{
DR. H. D. BENJAMINS
}

Het laatste verslag, dat „De West-Indische Gids” over deze aangelegenheid gaf, had tot hoofd „De Corantijnkwestie bij Buitenlandsche Zaken" en is te vinden in het nummer van April 1929 (10de jg. blz. 571-584).

Ten einde een behoorlijke aansluiting te verkrijgen met wat in dit elfde verslag zal volgen, moet ik het een en ander uit bovengenoemd artikel herhalen.

In de vergadering van de Tweede Kamer van 15 Februari 1928 zeide Minister Koningsberger:

„Van verschillende zijden is de grensquaestie weer in het geding gebracht. Ik zal daarvan thans niets zeggen dan dat, nu de zaak één keer in gang is gebracht, het ook mijn oprechte wensch is, dat zij zoo spoedig mogelijk tot een definitieve beslissing zal geraken. Schriftelijke en mondelinge gedachtenwisseling met mijn ambtgenoot van Buitenlandsche Zaken geven mij in dit opzicht goede verwachtingen".

Het betrof hier de Corantijnkwestie.

Bij de openbare behandeling van de begrooting van Buitenlandsche Zaken voor 1929 in de Tweede Kamer op 13 November 1928 zeide Minister Beelaarts van Blokland, in antwoord op een opmerking van den heer Droogleever Fortuyn, die niet in het Voorloopig Verslag voorkwam:

...., Een tweede voorbeeld was de grensregeling tusschen Suriname en Britsch-Guyana. Wij zullen die zeker hedenavond niet tot stand kunnen brengen. Men kan zeggen, dat de Regeering meer voortvarend moet zijn, maar bij dergelijke dingen gaat het er niet alleen om hoe wij er over denken, maar ook hoe een andere Regeering er over denkt. $\mathrm{Bij}$ internationale zaken kan men niet altijd vooruit zooals men wil; men moet wachten op het juiste oogenblik om een zaak te kunnen aanbrengen".

Moet men hieruit afleiden dat de Minister toen nog niet in overleg was getreden met de Britsche Regeering? 
In bovengenoemd artikel zeide ik nog, naar aanleiding van Jhr. Beelaerts' verklaring:

„Het wil mij toeschijnen, dat het, na het verschijnen van de nieuwste kaart van Britsch-Guiana en de bevestiging van Barrington Brown's ontdekking door de expeditie-Stahel, nu het psychologisch moment is".

Buiten de regeeringsbureaus wist men hier niets van den stand der grenskwesties. Men keek er dan ook van op, toen „De West" van 28 Juni 1929, onder het hoofd „Een inval in Suriname?” het volgende bericht bracht:

„Krijgen wij, na den inval op Curaçao, ook een inval in Suriname? Men zou dit afleiden uit het volgend bericht dat wij uit Albina ontvangen, gedateerd $26 \mathrm{Juni}$ : Onze districtscommissaris gaat overmorgen naar de Tapanahony. Volgens sommigen zou dit zijn ter installatie van Matodja of Kanapé, het nieuwe Opperhoofd der Aucaners. Volgens anderen houdt deze reis verband met berichten, dat een veertigtal Brazilianen over de grens gekomen zouden zijn en zich gevestigd hebben aan de Boven Tapanahony. De commissaris zou nu een onderhoud hebben met deze heeren, die intellectueelen worden genoemd. De geneesheer, dr. Faverij, gaat mede, zijn vervanger, dr. Hiemke, is reeds hier aangekomen ${ }^{*}$.

Het blad „Suriname” van 26 Juli 1929 bracht de oplossing in een bericht: „Brazilianen op ons grondgebied”:

„Onlangs deelde De West mede dat er berichten te Albina ontvangen waren dat Brazilianen zich in het Lawagebied op ons grondgebied hebben gevestigd. Nader vernemen wij, dat dit bericht juist is. Deze buren zijn evenwel geen indringers, zooals dit bericht zou doen vermoeden, doch leden van een wetenschappelijke expeditie, die met medeweten en goedvinden van ons bestuur in die streken onderzoekingen doen. Aan de Indianen ter plaatse deelden zij o.a. mede, dat zij de Goeje, leider van de Tapanahony-expeditie kennen.

Niet onwaarschijnlijk dat deze expeditie verband houdt met het verzoek van de Braziliaansche regeering middels haar zaakgelastigde in Den Haag, aan de moederlandsche regeering gedaan om de grens tusschen ons land en Brazilië vast te stellen".

„De West” van 26 Juli 1929 vulde zijn eerste bericht als volgt aan:

„De geruchten omtrent het binnendringen van Brazilianen op Surinaamsch grondgebied hebben een alleszins bevredigende oplossing gekregen. Er is in beginsel besloten, dat een gemengde expeditie de grens zal vaststellen tusschen Suriname en Brazilië. Onlangs heeft de Gouverneur bericht gekregen dat vanwege de Braziliaansche regeering eenige personen naar het grensgebied zijn gezonden ten einde eenige voorbereidende maatregelen te nemen, in verband met de later uit te 
zenden gemeenschappelijke expeditie. In verband daarmede heeft de districts commissaris van Marowijne, die onlangs naar het achterland een reis maakte, in opdracht van den gouverneur aan de plaatselijke bevolking verzocht eventueel alle medewerking te verleenen aan bedoelde Braziliaansche expeditie".

Dat verzoek aan „de plaatselijke bevolking” doet grappig aan.

Onder het hoofd „De grenzen van Brazilië" verscheen in de „Nieuwe Rotterdamsche Courant” van 31 Juli 1929 Av. bl. B. een belangrijk artikel, waaraan het volgende is ontleend:

„Er zijn berichten uit Britsch Guyana, dat de afbakening van de grenslijn tusschen Brazilië en genoemde kolonie spoedig zal worden ondernomen. Een verdrag, welk dit onderwerp regelt, zou kort geleden reeds in Londen geratificeerd zijn.

Minister dr. Octavio Mangabeira interesseert zich sterk voor een juiste afbakening der grenzen van geheel Brazilië en de Daily Chronicle te Georgetown vermeldt, dat een overeenkomst tot stand is gekomen met de omliggende landen en dat de tegenwoordige minister van buitenlandsche zaken op het oogenblik druk doende is met onderhandelingen voor de afbakening der grenzen met Fransch- en Nederlandsch Guyana (Suriname). De aan Brazilië grenzende landen zijn Fransch-Guyana, Suriname, Britsch-Guyana, Venezuela, Columbia, Ecuador, Peru, Bolivia, Paraguay en Uraguay.

Wat de zuidelijke grens van Suriname betreft, kan verwezen worden naar het op 5 Mei 1906 te Rio-de-Janeiro tusschen Nederland en Brazilië gesloten verdrag tot regeling der grens tusschen beide landen, welk verdrag is goedgekeurd bij de wet van 11 Juli 1908 (Staatsblad no. 220), waarvan de tekst bij K. B. van 28 December 1908 Stbl. no. 423 nevens de vertaling zijn afgekondigd in het gouvernementsblad van Suriname no. 31 van 1909 (resolutie van 21 Mei no. 6343). Dit geschiedde onder den minister van buitenlandsche zaken De Marees van Swinderen, toen Hare Majesteit de Koningin der Nederlanden en de President der Vereenigde Staten van Brazilië bezield waren „met den wensch de banden van vriendschap, die gelukkigerwijze tusschen de beide volken bestonden, nauwer aan te halen, en de geschillen te vermijden, die zouden kunnen ontstaan, indien de grens tusschen Brazilië en de kolonie Suriname niet bij tractaat ware vastgesteld"'.

In artikel 1 werd bepaald, dat de grens van de Fransche tot aan de Britsche grens gevormd wordt door de lijn der waterscheiding tusschen het stroomgebied der Amazone, in het Zuiden, en de bekkens der waterstroomen, die zich noordwaarts in den Atlantischen Oceaan uitstorten, terwijl in art. 2 werd bepaald, dat zoodra zij het nuttig oordeelen, de beide regeeringen commissarissen benoemen om de grens af te bakenen".

Verder heeft de schrijver het over het grensgeschil VenezuelaBritsch-Guiana, waarbij hij opmerkt dat een ernstig conflict werd voorkomen door het voorstel van wijlen Lord Salisbury om het geschil aan arbitrage te onderwerpen.

West-Indische Gids XII 
Deze opmerking is vermoedelijk ontleend aan „British Guiana" Handbook prepared under the direction of the historical Section of the Foreign Office, no. 135, London 1920.

„Het Koloniaal Weekblad" van 8 Aug. 1929 het stuk overnemende, verwijst den schrijver naar een artikel in "De West-Indische Gids" van December 1921, 3e jg. blz. 400, waarin van de toedracht der zaak, aan de hand van een geschrift van President Grover Cleveland een andere lezing wordt gegeven.

Is het niet eigenaardig dat men hier uit Surinaamsche en Demerary'sche bladen moet vernemen dat de Braziliaansche Regeering aan onze Regeering heeft voorgesteld om gezamenlijk de grens af te bakenen?

Genoemd „Koloniaal Weekblad" merkt nog het volgende op:

„Is het bericht uit Britsch-Guiana juist en zal het tot afbakening van de grens van Suriname met Brazilië komen, dan zal men - zoo de Corantijn- en de Marowijne-kwesties vóor dien niet zijn opgelost voor de vraag staan wat de taak van onze commissarissen bij de afbakening zal zijn. Als hiervoren gezegd, is volgens art. 1 van bovengenoemd tractaat met Brazilië bepaald dat de grens met Braziliē van de Fransche tot aan de Britsche grens gevormd wordt door de lijn der waterscheiding tusschen net'stroomgeoléa 'aer-Aluazone, iihet Zuiden, en de bekkens der waterstroomen die zich noordwaarts in den Atlantischen Oceaan uitstorten. Maar nòch de Fransche nòch de Britsche grens staan vast. De gebieden tusschen de Litani- en de Marowijnekreek eenerzijds en tusschen de Koetari-Koeroeni-New River anderzijds zijn betwist gebied. Wie zal nu de waterscheiding tusschen deze gebieden en Braziliē te zamen met de Braziliaansche commissarissen afbakenen? Springt het niet in het oog dat eerst zoowel de westals de oostgrens van Suriname bij tractaat geregeld moeten zijn? Welk bescheid zal onze regeering aan de Braziliaansche moeten geven als het voorstel tot afbakening der grens is of wordt gedaan?

Eindelijk verlangde de Tweede Kamer te weten wat er gaande was.

In haar Voorloopig Verslag, gedagteekend 18 October 1929, betreffende de begrooting van Buitenlandsche Zaken voor 1930 lees ik:

„§5. Grenzen van Suriname. Inlichtingen werden gevraagd, omtrent het voorstel, dat, naar men meende te weten, door Braziliě in zake de afbakening van de grens tusschen dat land en Suriname is gedaan. Met name zou men wenschen te vernemen, hoe dit voorstel luidt en welk standpunt de Regeering daartegenover inneemt.

Intusschen werd er de aandacht op gevestigd, dat alvorens tot een grensregeling met Brazilië wordt overgegaan, de nog steeds hangende regeling van de grens tusschen Suriname en Britsch Guyana behoort te zijn vastgelegd". 
De Memorie van Antwoord, ingezonden 6 November 1929, gaf het volgende bescheid:

„\$ 5. Grenzen van Suriname. De Braziliaansche Regeering, die er naar streeft aan alle zijden de grenzen van Brazilië nauwkeurig af te bakenen, heeft zich met een beroep op art. 2 van het op 5 Mei 1906 te Rio de Janeiro tusschen Nederland en Brazilië gesloten Verdrag (Staatsblad no. 220 en 1908), waarbij de grens tusschen Brazilië en Suriname werd vastgesteld, maar waarbij werd bepaald, dat de eigenlijke afbakening der grens door commissarissen zou plaats hebben wanneer de Regeeringen dit nuttig zouden achten, tot de Nederlandsche Regeering gewend, met het verzoek er toe mede te werken om thans tot die afbakening over te gaan. De Nederlandsche Regeering heeft zich daartoe bereid verklaard.

Daar, zooals terecht wordt opgemerkt, het wenschelijk was, dat tusschen Groot-Britannië en Nederland geen verschil van meening bestond nopens het knooppunt van de grenzen van Brazilië, Suriname en Britsch-Guyana, terwijl ook op zichzelf de vastlegging van de grens tusschen Suriname en Britsch-Guyana wenschelijk is, heeft de ondergeteekende inleidende besprekingen met de Britsche Regeering over deze vaststelling geopend. Desgelijks zijn, om gelijke redenen, met de Fransche Regeering besprekingen geopend terzake van de nadere vastlegging van de grens tusschen Suriname en Fransch-Guyana”.

„Het Koloniaal Weekblad van 14 November 1929 teekende hierbij aan:

„De afbakening van de grenzen in het onbewoonde binnenland is geen kleinigheid. Toch behoeft die niet zoo tijdroovend te zijn als zij een 30-tal jaren geleden zou geweest zijn .De bronrivieren van Corantijn en Marowijne zijn met watervliegtuigen in eenige uren te bereiken. Toch zullen het kostbare ondernemingen zijn. Wij mogen daartegen niet opzien. De vaststelling langs scheidsrechterlijken weg van de grenzen van Britsch-Guiana met Venezuela en Brazilië en van Fransch Guiana met Brazilië heeft aan de respectieve landen zeer veel geld gekost. Wij moeten er op voorbereid zijn dat wij er niet op een koopje afkomen" ${ }^{1}$ ).

Bij de openbare behandeling van de begrooting is er in de Kamer over de zaak niet gesproken.

Het Voorloopig Verslag der Tweede Kamer, gedagteekend 19 December 1929 betreffende de Surinaamsche begrooting voor 1930 kwam op de grenskwestie Suriname-Britsch Guiana terug:

„Grensregeling. Opnieuw werd gevraagd naar den stand van het vraagstuk der regeling van de grens tusschen Suriname en Britsch-

1) Reeds in het artikel „De Corantijnkwestie bij Buitenlandsche Zaken", in "De West-Indische Gids" van April 1929 werd op blz. 581 het gebruik van vliegtuigen aanbevolen. 
Guyana. Mede in verband met het onderzoek naar de aanwezigheid van delfstoffen in Suriname werd het van groot belang geacht, dat deze reeds zoo lang hangende quaestie thans eindelijk wordt opgelost".

De inmiddels weer opgetreden Minister van Koloniën, de heer de Graaff, verklaarde in zijne, op 28 Januari 1930 ingezonden Memorie van Antwoord:

„De Braziliaansche Regeering heeft het verzoek gedaan om in gemeenschappelijk overleg de grenzen tusschen Brazilië en Suriname af te bakenen. De Nederlandsche Regeering is op grond van art. 2 van het bij de wet van 11 Juli 1908 (Staatsblad no. 229) goedgekeurde verdrag van 5 Mei 1906 gehouden hiertoe hare medewerking te verleenen. Gelijktijdig zullen echter in gemeenschappelijk overleg met onderscheidenlijk de Fransche en de Engelsche Regeeringen moeten worden vastgelegd de aan weerszijden van Suriname gelegen drie-landen punten. De eerste stappen voor dit overleg zijn reeds gedaan".

In „Het Koloniaal Weekblad” van 6 Februari 1930 deze opmerkingen:

„Al gaat het voor gemeenschappelijke rekening, de afbakening zal, vooral door den langen duur van het werk, zeer veel geld kosten. Wat het gebruik van watervliegtuigen betreft, spreekt het van zelf, dat men van te voren voor de landing geschikte rivierdeelen zal moeten uitzoeken. De bronrivieren hebben veelal rotsachtige beddingen en zijn niet zelden vol omgevallen boomen. en misschien zijn er in het grensgebied Savannes, die gemakkelijk tot vliegveld gemaakt kunnen worden. Op de foto's no. 22, 23 en 24 in de Goeje's „Verslag der Toemoekhoemak-Expeditie" zien wij Savannes afgebeeld op $2^{\circ} 8^{\prime} 40^{\prime \prime} \mathrm{N}$. Br. en $56^{\circ} 13^{\prime} 20^{\prime \prime}$ W' L. Gr. Misschien zijn er meer".

En in het nummer van 13 Februari nog het volgende:

„Ons wordt gevraagd of bij de afbakening van de grenzen van Suriname te allen tijde, „zoo maar” gebruik kan worden gemaakt van vliegbooten of landvliegtuigen. Neen, ,zoomaar” kan dat natuurlijk niet. Óveral ter wereld moeten landingsterreinen worden voorbereid. Hier door vóór-expedities, hetzij de machines landen op Savannes, hetzij de landing op het water geschiedt. In het laatste geval zullen de vliegbooten waarschijnlijk niet kunnen landen in het Zuidelijkste deel van de bronrivieren, omdat deze te smal zullen blijken, vol omgevallen boomen en bezaaid met vallen en stroomversnellingen. In het droge jaargetijde hebben ze weinig water en in den grooten regentijd stroomt het water met groote snelheid noordwaarts. Een nauwkeurig vóoronderzoek zal noodig zijn. Maar het gebruik van vliegtuigen zal onvermijdelijk zijn voor het afvoeren van zieken en verlofgangers en voor het aanvoeren van versche levensmiddelen, teneinde het uitbreken van zwelziekte te voorkomen. Het opvaren van de rivieren duurt vele weken en ook het afvaren is zeer tijdroovend. Daar waar Litanie en Marowijnekreek eenerzijds en Koeroeni en New River anderzijds samenvloeien, zullen vliegbooten te allen tijde kunnen landen, mits ook dáár 
van te voren de terreingesteldheid wordt opgenomen. Van de kust worden deze punten in eenige uren bereikt terwijl de reis te water, als gezegd, vele weken duurt en niet zonder gevaar is.

Wordt er van vliegtuigen gebruik gemaakt, dan komen de expeditieleden niet afgemat of ziek op het terrein hunner werkzaamheid aan.

Hoe men de afbakening denkt te doen, weten wij niet. Ons wil het toeschijnen, dat het aanbrengen van betonnen of gemetselde grenspalen op bepaalde afstanden niet noodig is. Heeft men het tracée over de waterscheiding astronomisch vastgelegd, dan kan daarmee o. 1. worden volstaan. Het tracée groeit toch spoedig weer dicht en de grenspalen verdwijnen in het oerwoud of zakken weg in de verweerde massa, die de heuvel- en bergruggen bedekt, zoo ze al niet door de Indianen worden verwijderd als deze daarin iets geheimzinnigs zien.

Is eenmaal de afbakening geschied, dan kijkt niemand meer daarnaar om, of er grenspalen staan al dan niet. Alleen bij de drielandenpunten ter weerszijden van Suriname - waarvan de aanwijzing, al worden wij het omtrent de grensrivieren met Engeland en Frankrijk eens, zeer veel hoofdbreken zal kosten - is het misschien wenschelijk grenspalen aan te brengen.

Teneinde de expeditieleden in de gelegenheid te stellen in gemeenschap te blijven met de bewoonde wereld, zal het wenschelijk zijn, radio-zend- en ontvanginstallaties mede te nemen.

Hoelang zal die afbakening duren? Dat is onmogelijk vooruit te zeggen. In die afgelegen, geheel onbewoonde oerwouden kunnen zich allerlei onvoorziene moeilijkheden voordoen. En de af te bakenen lijn is zeer lang. Men bekijke de kaart maar eens.

Britsch Guiana en Venezuela hebben na de uitspraak van het $\mathrm{Pa}$ rijsche scheidsgerecht de grens afgebakend. Het werk der gemengde commissie begon op 12 September 1901 en eindigde - met eenige onderbrekingen - in het begin van 1905 .

$\mathrm{Na}$ de beslissing van de grenskwestie tusschen Britsch Guiana en Brazilië door den Koning van Italië, in 1904, werd de afbakening op 25 Januari 1906 aangevangen. In het najaar van 1906 was het werk gedaan, dus in veel korter tijd dan de Venezuelaansche grens. Of er grenspalen gezet zijn, weten wij niet. In „Storm van's-Gravesande, The rise of British Guiana, compiled from his dispatches", by C. A. Harris en J. A. J. de Villiers, Vol. I, London, printed for the Hakluyt Society, 1911, waaraan wij vorenstaande mededeelingen ontleenen, vinden wij, in een noot op blz. 126 aangeteekend, dat Mr. C. W. Anderson, as boundary commissioner, een boundary mark geplaatst heeft op het Roraima gebergte, waar Britsch Guiana, Venezuela en Brazilië te zamen komen.

De verslagen der afbakenings-commissies zijn aangeboden aan de Court of Policy in Britsch Guiana, maar zijn, volgens een mededeeling in een noot op blz. 140 van evengenoemd boek, ,not at present generally accesible or easy to obtain". Wellicht zijn ze aanwezig op het Departement van Koloniën. De studie daarvan kan van groot belang zijn voor hen, die de zware taak zullen aanvaarden de grenzen af te bakenen".

Ik teeken hierbij aan dat niet kan bedoeld zijn de afbakening van de geheele grens tusschen Brazilie en Britsch-Guiana. Dat is 
goed ook, anders zou er zijn vooruitgeloopen op de beslissing van de grenskwestie Suriname-Britsch Guiana.

En nu weer terug naar de Tweede Kamer. Bij de openbare behandeling van de Surinaamsche begrooting voor 1930 op $11 \mathrm{Fe}-$ bruari 1930, zeide de heer van Kempen:

„Noodig schijnt mij ook een snelle regeling van de bepaling van de grenzen. Ik heb tot mijn genoegen in de stukken gezien, dat men daar voortgang mee maakt. De regeling der grenzen worde bespoedigd om zeker te zijn van de ligging der terreinen, waarin eventueele minerale rijkdommen, welke op welkome ontginners wachten, gevonden worden. Een conflict op de grens van Nederlandsch en Portugeesch Timor geeft een sterke illustratie van de noodzakelijkheid, dat de grenzen bekend zijn. Juist aan de overzijde van de betwiste grens bleken groote olierijkdommen te zitten. Portugal is toen in het gelijk gesteld en wij hebben het terrein moeten missen. Bij de autoriteiten bestond er groote onzekerheid, wie de olie zou krijgen en voor hen, die de courage hadden de expoltatie te beginnen, was deze onzekerheid ook zeer storend".

Niet minder dringend was hetgeen de heer Feber te berde bracht:

„Nog slechts een punt zou ik willen aanroeren in aansluiting aan wat ook de heer van Kempen heeft besproken. Naar mijn meening zou het zeer gewenscht zijn, dat uitermate bekwame spoed werd betracht ten aanzien van alle quaesties betreffende de grensregeling van de kolonie Suriname en wel o.a. in verband met de omstandigheid, dat de mogelijkheid is gebleken, dat de Surinaamsche bodem rijke minerale schatten bevat. Het komt mij voor, dat onder deze omstandigheden de heer van Kempen wees op het voorbeeld van Timor - de grensquaesties, die thans nog betrekkelijk gemakkelijk te regelen zijn, over eenige jaren wel eens vol haken en oogen zouden kunnen zitten en dat wij dan door te weinig voortvarendheid ons zouden hebben begeven in moeilijkheden, die door een voortvarende politiek zeer wel waren te vermijden geweest"'.

Het antwoord van den Minister, in de vergadering van $12 \mathrm{Fe}-$ bruari luidde:

„Een onderwerp, dat geheel buiten de lijn van de bespreking ligt, is de grensafbakening van Suriname. In de gedrukte bescheiden is medegedeeld, dat dit punt binnenkort tot een oplossing zal komen in verband met de voorgenomen vastlegging van de grenslijn met Brazilië. Een gemengde commissie, bestaande uit vertegenwoordigers van Brazilië, Engeland, Frankrijk en Nederland zal zich met dat grensonderzoek bezighouden, en van zelf komt dan ook de quaestie van de twee z.g. drielandenpunten daarbij aan de orde, zoodat ook voor Suriname de zaak daarmede tot een beslissing zal komen". 
Repliceerende zeide de heer van Kempen:

„Mijn tweede vraag is deze. Ik heb gehoord, dat de grenscommissiën langzamerhand aan het werk zullen gaan, maar ik zou graag van den Minister willen weten, of hij kan zeggen, of die zaak ook met spoed zal afloopen. Ik herinner aan de grensregelingen in Timor en Borneo, die bij gemis van voortvarendheid en druk, uitgeoefend op degenen, die daarvoor hadden te zorgen, jaren en jaren hebben geduurd.

In het belang van Suriname zou ik er op willen aandringen, dat de grensregeling zoo gauw mogelijk tot stand komt".

Waarop de Minister antwoordde:

„Wat aangaat de grensregeling in Suriname deel ik het standpunt van dien zelfden geachten afgevaardigde, dat het daarbij niet alleen op zich zelf een nuttige zaak betreft, maar dat het ook wenschelijk is, de regeling zoo spoedig mogelijk tot stand te brengen. Uit den aard der zaak is het niettemin een werk van betrekkelijk langen duur, dat minstens één of twee jaren zal vorderen, te meer omdat het verschillende landen aangaat, die onderling moeten samenwerken en het een vrij kostbare maatregel betreft. Het spreekt overigens vanzelf, dat de commissie zich beijveren zal, zoo spoedig mogelijk haar taak te voltooien".

Het is jammer dat de heeren van Kempen en Feber den nadruk leggen op den mogelijken mineralen rijkdom van den bodem in het betwiste gebied tusschen Suriname en Britsch-Guiana.

Ik deel in deze kwestie de meening van den heer Yzerman, die bij de openbare behandeling van de begrooting van Buitenlandsche Zaken in de vergadering van de Tweede Kamer op 10 November 1925 zeide:

„Hoe die grens wordt vastgesteld, is voor Suriname geen levensquaestie, maar dat zij wordt vastgesteld, is voor Suriname van groot belang”. (Zie „De W. I. Gids” van November 1926, 8ste jg. blz. 300).

Reeds in mijn artikel „De grenzen van Nederlandsch Guiana”, in het "Tijdschrift van het Kon. Nederl. Aardr. Genootschap", December 1898, schreef ik, op blz. 823, omtrent dit betwiste gebied:

„Niet om het stuk misschien geheel waardeloos land tusschen de bronrivieren van de Corantijn moet het ons te doen zijn, maar om het recht van het spel!

Stond de zaak juist andersom, men zij er van verzekerd dat Engeland het beschouwen van het bewuste stuk land als Nederlandsch gebied niet zou dulden".

Het is niet duidelijk wat de Minister bedoelt, waar hij spreekt van ,een gemengde commissie, bestaande uit vertegenwoordigers van Brazilië, Engeland, Frankrijk en Nederland". Een commissie 
kan niet bedoeld zijn. Voor het afbakenen van de grens met Brazilië, tusschen de bronnen van de Litani en de Koetari-Koeroeni hebben onze commissarissen alleen te maken met de Braziliaansche commissie. Met het vaststellen van het drielanden punt Fransch-Guiana-Suriname-Brazilië hebben de Engelschen niets te maken, evenmin als de Franschen behoeven mede te werken aan de vaststelling van het drielanden punt Britsch-Guiana-Suriname-Brazilië.

Het wil mij voorkomen dat de Minister, die, waar het Surinaamsche aangelegenheden betreft, alles behalve optimistisch is, dat in zijn antwoorden wèl is. De commissieleden schijnen nog niet eens benoemd te zijn. En de grensregelingen met Engeland ${ }^{1}$ ) en Frankrijk, die vooraf moeten gaan aan de afbakening, zullen misschien niet zoo vlotten als wenschelijk is.

Waar de Minister spreekt van grensregeling bedoelt Zijne Excellentie waarschijnlijk grensafbakening.

Intusschen zijn de Brazilianen, blijkens de mededeelingen uit Suriname, reeds eenigen tijd aan het werk.

Ook de Engelsche commissarissen zijn reeds vertrokken.

Aan „The Daily Argosy" - een in Britsch-Guiana verschijnend blad - van 16 en 20 Maart 1930 ontleen ik de volgende berichten:

16 Maart.

„Instructions having been received from the Secretary of State for the British Guiana Brazilian Boundary Commission to proceed, a party composed of Messrs. Wm. Cunningham, Superintendent of Surveys, A. J. Cheong and W. T. Lord, surveyors of the Department of Lands and Mines, Dr. A. Fung and Mr. W. Vincent, dispencer, will leave Georgetown on Wednesday for the Rupununi where they will be joined by Mr. C. King, interpreter who preceded the party for the purpose of making advance arrangements for the employment of Labour. The

1) Naar aanleiding van de Corantijn-kwestie zij hier aangeteekend dat mij de vraag is gedaan of de Engelschen, na Barrington Brown's ontdekking van de New River, de bronrivieren van de Corantijn hebben geëxploreerd. Berichten daaromtrent zijn mij niet bekend, maar ik moet wel aannemen dat die latere exploratie heeft plaats gehad. Op de jongste kaart van Britsch-Guiana - die van 1924, te vinden o.a. in "Report of the British Guiana Commission", April 1927 - worden n.l. enkele zijrivieren van de New River met name genoemd, wat niet het geval was op de kaart van Brown. Op de kaart van 1924 wordt de New River, evenals bij Brown, afgebeeld als een belangrijker rivier dan de Koetari-Koeroeni, zooals ook de bevinding was van de expeditie-Stahel. 
Mission is the result of a Treaty between His Majesty the King and the President of the Brazilian Republic for a joint Commission between British Guiana and Brazil for the settlement of the boundary between British Guiana and Brazil.

The British Guiana party who will join the Brazilian Commission on the Brazilian frontier will be away from Georgetown for about 15 months. They will be leaving at a most unfavourable time of the year as the rainy season is about to commence in the savannahs. It is therefore proposed to struggle through the wet season and take full advantage of the long dry season, returning to Georgetown at the beginning of the wet season in May, 1931.

20 Maart:

The members of the British Guiana Brazilian Boundary Commission will leave Georgetown this morning for the Rupununi via Bartica. The party should have left Georgetown yesterday but delayed their departure in order to obtain some new surveying instruments which arrived bij the S. S. Ingoma on Monday afternoon. The members of the party are Messrs. Wm. Cunningham, Superintendent of Surveys, who has been appointed Chief Commissioner, A. J. Cheong (Deputy Commissioner) and W. T. Lord, relief surveyors, Dr. A. Fung and Mr. W. Vincent. Government dispenser. From Bartica the party will travel in special boats up the Rupununi as far as Yupukari where they will join the Brazilian Commission and mr. Cyrill King, clerk, interpreter and transport officer who preceded the party. Accompanying the party are a crew of 70 labourers about half of whom are Indians.

The demarkation of the boundary between British Guiana and Brazil is estimated to occupy five years, but the British Guiana Commission is expected to return to Georgetown at the beginning of the wet season in May, 1931.

Quarterly reports on the progress of the work will be made to the Secretary of State and the Commission is requested to take the care to adhere scrupulously to the formalities of producing accurate Portuguese and English versions of any joint reports and recommendations which may be prepared for the consideration of the British and Brazilian Government in order to avoid the serious delays which have been caused in connection with other boundaries bij the discovery of discrepancies in the two texts after the Commission has separated".

Zoover zijn wij nog lang niet. De mededeelingen van de Regeering zijn sober. Bij de opening van de zitting der Koloniale Staten op 13 Mei 1930 heeft Gouverneur Rutgers gezegd:

„Zooals reeds bleek uit de begrootingsdebatten, voor enkele maanden in de Tweede Kamer der Staten-Generaal gehouden, overweegt de Regeering de uitzending van eenige expedities ten laste van de Nederlandsche Staatsbegrooting, met het doel de grenzen van Suriname vollediger vast te stellen en af te bakenen".

Overweegt! Terwijl de Engelsche expedities er reeds op uitgetrokken zijn.

Andere officieele berichten uit Suriname zijn mij niet bekend. 
$\mathrm{Al}$ wat hier naar buiten is gebleken, is dat de Minister van Kolonien op 30 Mei 1930 bij de Tweede Kamer heeft ingediend een wetsontwerp tot wijziging en verhooging van het XIe hoofdstuk der Rijksbegrooting voor 1930. Een der nieuwe artikelen ad $f 100.000$ betreft de kosten verbonden aan de uitzending van een expeditie om in overleg met vertegenwoordigers van de Braziliaansche Republiek de Zuidgrens van Suriname af te bakenen.

Van regeling en afbakening van de grenzen van Suriname met Britsch- en Fransch-Guiana wordt hier niet gesproken. Zullen daarmede geen kosten gespaard gaan?

De Minister verklaart dat nauwkeurige raming van het benoodigd bedrag en den benoodigden tijd niet te geven is. Hierbij is het volgende op te merken: het zal een aanmerkelijk verschil maken zoowel in de kosten, als in den duur der afbakeningen of wij zullen hebben af te bakenen van af de bronnen van de Litani tot die van de Koetari, dan wel van die van de Marowijnekreek tot die van de New River. Hierbij komen nog wellicht kosten van de afbakening van de grenzen van Suriname met Fransch en Britsch Guiana, indien het niet tot een regeling langs diplomatislesn wogrlonmt

Wil men onze commissie voorzien van alle moderne hulpmiddelen dan is het te verwachten dat de kosten nog hooger worden.

Het op 12 Augustus 1930 vastgestelde Voorloopig Verslag der Tweede Kamer betreffende dezen begrootingspost luidde:

„Ad art. 13b. Vele leden juichten het toe, dat thans in overleg met de Braziliaansche Regeering zal worden overgegaan tot vaststelling van de grens tusschen dit land en Suriname. Men sprak voorts de hoop uit, dat het met de Britsche en de Fransche Regeeringen geopende overleg thans ook spoedig zou leiden tot vaststelling van de grenzen tusschen Suriname en de Britsche en Fransche gebieden en aldus aan de befaamde grensquaesties van Suriname een einde zal worden gemaakt.

Gevraagd werd of het reeds een punt van overweging heeft uitgemaakt, de vanwege Nederland uit te zenden expeditie voor haar arbeid ook gebruik te doen maken van vliegtuigen".

Inmiddels moeten wij genoegen nemen met niet te controleeren mededeelingen en geruchten in de Surinaamsche bladen. Het is te hopen dat, wanneer de expedities vertrokken zijn, de Regeering nu en dan mededeelingen zal doen over den gang der werkzaamheden, opdat men, om iets te weten te komen, niet zal behoeven te snuffelen in buitenlandsche bladen. Publicatie van de periodieke rapporten der expeditie is gewenscht. 
Hier volgen nu eenige berichten uit de Surinaamsche bladen: Uit „De Surinamer” van 23 Maart 1930:

„Dezer dagen werd ons uit Albina bericht, dat er van overheidswege met Boschnegers onderhandeld werd over huur van een groot aantal corjalen, men sprak van 25 , voor een bijzondere expeditie. Men meende te weten, dat deze verband moet houden met een geschil tusschen de Fransche overheid en de onze omtrent de uitgifte door de Franschen van een concessie, die feitelijk op Nederlandschen grond zou liggen en nu bezocht zou worden door een expeditie, waarbij heeren uit Nederland zouden zijn. Bij navraag bleek ons, dat er inderdaad prijsopgave was gevraagd ten behoeve van een expeditie, doch dat deze voor een geheel ander doel zou uittrekken. Van een geschil is er geen sprake. Het gaat om de vaststelling der grenzen tusschen de drie Guyana's en Brazilië.

Eenigen tijd geleden berichtten wij reeds, dat de Brazilianen bezig waren de grens te verkennen en met toestemming zijdens de Regeering daarbij waren doorgedrongen tot ons grondgebied. De werkzaamheden zijn thans in zulk een stadium gekomen, dat nu de gezamenlijke vaststelling moet plaats vinden door Brazilië en de Moederlandsche Regeeringen der drie Guyanas.

In verband daarmede werd nu onderzocht op welke voorwaarden corjalen zouden te krijgen zijn voor een eventueelen tocht naar 't grensgebied langs de Marowijne. Of men dezen weg zal kiezen staat nog niet vast. Waarschijnlijk gaat men langs de Amazone, waarschijnlijk ook (gedeeltelijk) over de Marowijne. Ten einde hieromtrent een beslissing te nemen worden dezer dagen de gegevens verzameld, waarvan in ons bericht sprake was".

\section{„De West" van 11 April 1930 schrijft}

„dat men doende is het noodige voor te bereiden voor het uitzenden van drie expedities naar de Braziliaansche grens en wel langs de volgende routes: Corantijn-Koeroeni-Sipaliwini, Marowijne-TapanahoniPaloemeu, Marowijne-Lawa-Litani. Hiervoor worden zestig korjalen gehuurd, met een groot aantal opzichters, arbeiders, enz.

Er wordt beweerd, dat bij een der jongste verkenningen de Braziliaansche generaal Rondo per vliegtuig neergedaald is in het Savannegebied nabij de Zuidgrens van Suriname" 1).

\section{„De West" van 29 April bericht nog dit:}

„In verband met de voorgenomen vaststelling van de grenzen der kolonie, zal, zooals wij reeds vroeger vermeldden, worden nagegaan of daarbij gebruik kan worden gemaakt van vliegtuigen. De vraag is of de natuurlijke gesteldheid van de savana's nabij de Zuidergrens van dien aard is, dat vliegtuigen daar kunnen neerdalen. Met de Pan American

1) Over de verrichtingen der Brazilianen zie: Gastão Cruls „A Amazonia que eu vi. Obidos-Tumucumaque", Prefacio de Roquette Pinto; Rio de Janeiro 1930. (Met illustratiés en een kaart). - Zie de bespreking door C. H. de Goeje in „De W. I. Gids” van Oct. 1930. 
Airways wordt onderhandeld om een verkenning voor dit doel te doen plaats vinden. Het vliegtuig kan in één dag heen en weer vliegen naar de Zuidgrens. De landmeter Currie zal meegaan voor de verkenning". .

Over deze „onderhandeling” heb ik in de Surinaamsche bladen verder niets gelezen.

$\mathrm{Na}$ dit relaas eenige beschouwingen over de grensafbakening. Welk deel daarvan zal verricht moeten worden door de Nederlandsche en de Braziliaansche commissarissen gezamenlijk?

Dat zal afhangen van de plaats der drielandenpunten Suriname -Britsch-Guiana-Brazilië eenerzijds en Suriname-FranschGuiana-Brazilië anderzijds. Aan de vaststelling daarvan zal een beslissing moeten voorafgaan van de grenskwesties van Suriname met zijn westelijke en oostelijke buren. Er moet n.l. worden uitgemaakt of in het brongebied van de Corantijn de Koetari-Koeroeni dan wel de New River, en in het brongebied van de Marowijne of de Litani dan wel de Marowijne-kreek respectievelijk de westelijke en de oostelijke grens van Suriname vormen.

Hoever de onderhandelingen van onze Regeering met de Britsche en de Fransche Kegeeringen gevorderd zijn is naai vuiten niet gebleken.

Wat de westelijke grens betreft is er alle reden om te verwachten dat de New River als de grens zal worden aangewezen. Engeland heeft toch geen enkelen redelijken grond om te volharden in de opvatting dat de Koetari-Koeroeni als de grens moet gelden, waar toch zoowel van Engelsche als van Nederlandsche zijde, na behoorlijke opmetingen, is uitgemaakt dat de New River de hoofdrivier is.

In den loop dezer grenskwestie heeft de Britsche Regeering ons niet behoorlijk behandeld. Ik zal dit hier niet op nieuw gaan betoogen na al de artikelen in dit tijdschrift aan deze kwestie gewijd. De lezer zij verwezen naar de artikelen „De grenzen van $\mathrm{Su}$ riname” (W. I. Gids, Nov. 1920, 2e jg. blz. 343-346), „De Corantijnkwestie op den goeden weg?" (W. I. Gids, Nov. 1926, 8ste jg. blz. 310) en „Hoe staat 't thans met de Corantijnkwestie?” (W. I. Gids, Dec. 1927 9de jg. blz. 404 409).

De Departementen van Koloniën en van Buitenlandsche Zaken zullen zeker over voldoende gegevens beschikken om het $\mathrm{Ne}-$ derlandsche standpunt en daarmede het recht te doen zegevieren.

In dat geval zal het afbakenen van de basis van den driehoek, gevormd door de Koeroeni-Koetari en de New River door de Braziliaansche en de Nederlandsche commissie moeten geschieden. 
Zoo eenvoudig als de Corantijn-kwestie is de zaak aan Suriname's oostgrens niet.

Wijlen Czaar Alexander III, die in Mei 1891 als scheidsrechter - voorgelicht door wijlen Prof. de Martens - een beslissing gaf in het grensgeschil tusschen Fransch Guiana en Suriname, overwoog

„que le Gouvernement Hollandais ainsi que le démontrent des faits non contestés par le Gouvernement Français entretenait à la fin du siècle dernier des postes militaires sur l'Awa;

que les autorités françaises de la Guyane ont maintes fois reconnu les nègres établis sur le territoire contesté comme dépendants médiatement ou immédiatement de la domination hollandaise, et que ces autorités n'entraient en relation avec les tribus indigènes habitant ce territoire que par l'entremise et en présence du représentant des autorités coloniales hollandaises;

qu'il est admis sans conteste par les deux pays intéressés que le fleuve Maroni, à partir de sa source, doit servir de limite entre leurs colonies respectives.

que la commission mixte de 1861 a recueilli des données en faveur de la reconnaissance de l'Awa comme cours supérieur du Maroni";

en besliste op die gronden:

"que l'Awa doit être considérée comme fleuve limitrophe, devant servir de frontières entre les deux possessions".

„En vertu de cette décision arbitrale le territoire en amont du confluent des rivières Awa et Tapanahoni doit appartenir désormais à la Hollande"....

Op den voorgrond zijn dus door den scheidsrechter onze historische rechten geplaatst. Het aardrijkskundig motief komt op de tweede plaats.

De gemengde commissie ${ }^{1}$ ) van 1861 had uitgemaakt dat de Lawa de hoofdrivier is. Hier vielen de historische en aardrijkskundige overwegingen samen. Maar hoe zou de beslissing zijn geweest, indien de commissie had bevonden, dat de Tapanahoni de hoofdrivier was? Zou de arbiter, waar hij de historische rechten op den voorgrond heeft geplaatst, niettemin het betwiste gebied aan Nederland hebben toegewezen?

Achteraf kan men nu zeggen dat de Nederlandsche Regeering, toen zij in 1888 met de Fransche Regeering de bemiddeling van den Czaar inriep, zich alleen op onze historische rechten had moeten beroepen; maar die weg was afgesneden door de benoeming

1) Nog altijd is het wenschelijk het zeer belangrijke verslag van de Hollandsche leden te publiceeren. 
van de gemengde commissie van 1861, die had uit te maken wat de hoofdrivier was. Een aardrijkskundig vraagstuk.

De Franschen hadden er belang bij er een aardrijkskundig vraagstuk van te maken.

Verder de Lawa opvarende kwam de commissie aan de samenvloeiing van de Litani en de Marowijnekreek. Op grond dat de Litani aan de monding breeder was dan de Marowijnekreek en dat haar richting meer in het verlengde lag van de Lawa besloot de commissie de Litani te beschouwen als de voortzetting van de Lawa en die rivier op te varen. De Marowijne-kreek werd niet opgenomen.

Dit was een fout. Een smallere monding is op zich zelf geen bewijs dat de rivier kleiner is. Dat een zijrivier op eenigen afstand van de monding zich verbreedt is een verschijnsel dat meermalen voorkomt ${ }^{1}$ ).

Er is nog een andere reden waarom de gemengde commissie de Marowijne-kreek had moeten exploreeren, het feit n.l.dat de in deze kreek gewoond hebbende Indianen en Boschnegers - die uit den aard der zaak grondig bekend waren met de hydrographie van de streek = haar denzelfden naam geven als aan de hogfdrivier, die bij hen Maroewini heet.

Henri Coudreau, die beide rivieren heeft geëxploreerd, noemde de „Marawini-crique” een „grand affluent, jusqu' alors inconnu du fleuve Maroni”. („Bulletin de la Société de Géographie Commerciale de Paris", 1888, XI, no. 1).

1) Een illustratie hiervan vindt men in het in 1929 te Rotterdam verschenen boek van Pater W. Ahlbrinck ,Vijf maanden in het oerwoud"'. Op blz. 98/99 schrijft hij:

„De Aramatau wordt als zijrivier beschouwd, die in de Koetari uitmondt. Dit blijkt wel hieruit, dat de vereenigde stroom tot aan zijn samenvloeiing met de Sipaliwini drie uur verderop niet Aramatau, maar Kutari heet.

Barrington Brown heeft den mond der Kutari en Aramatau opgenomen en bevonden dat de laatste 9 voet minder breed en 9 voet minder diep is dan de eerste. Zoo schijnt de zaak dus uitgemaakt, de Aramatau is de kleinste, de Kutari de grootste, de hoofdstroom.

Waar de rivieren niet al te groot zijn, gelijk bij de twee onderhavige rivieren het geval is, zal de uitmonding op zich [zelf] slechts dan een goed criterium kunnen zijn, wanneer bij beide stroomen de bouw der bedding dezelfde of ten naastenbij dezelfde is"'.

Pater Ahlbrinck's bevinding was :

„De Kutari is bij haar uitmonding het sterkste, doch neemt opgaande zeer spoedig af, wordt zeer nauw en ondiep, is met struikgewassen herhaaldelijk overgroeid, gelijkt op een kreek. De Aramatau is bij haar uitmonding het zwakst, verbreedt zich echter reeds spoedig en wordt boven hare vallen een breede, diepe, statige rivier." 
Ook met het feit dat in de Marowijnekreek gedurende vele jaren Surinaamsche negers hebben gewoond ${ }^{1}$ ) had de commissie rekening moeten houden. In opdracht van het Surinaamsche Bestuur zijn de in deze kreek wonende Boni-negers door de Aucaners, onder aanvoering van Bambie, van 22 Januari tot 2 Maart 1793 vervolgd („Surinaamsche Staatkundige Almanak voor den jaare 1796 ", door Charles Brown, blz. 87 vlg.) en van 3 November tot 6 December 1793 door de expeditie onder majoor Zeegelaar van uit den militairen post aan de Lawa. (Zie Zeegelaar's journaal in het Rijksarchief. Inv. No. 149, stuk no. 764).

Bij J. N. Crevaux „Voyages dans l'Amérique du Sud”, Paris 1883, blz. 266 een stellige aanwijzing dat de in het grensgebied wonende Roekoejana-(Ojana-) Indianen de Nederlandsche troepen hebben gezien $\left.{ }^{2}\right)$.

In zijn boek „Chez nos Indiens, Quatre années dans la Guyane française (I887-I89I)". Paris 1893, blz. 36, zegt Coudreau destijds een der krachtigste verdedigers van het Fransche standpunt in het Lawa-Tapanahoni geschil - dat volgens zijn jongste exploraties de beide rivieren Litani en Marowijnekreek „à peu près d'égale importance" zijn.

Hij bedoelde waarschijnlijk dat de Litani iets grooter is, maar uit de bij het boek gevoegde kaart „Guyane française, d'après les plus récentes explorations", publiée par la Société de Géographie, Paris 1892, krijgt men niet den indruk dat de Marowijne-kreek belangrijk kleiner is dan de Litani. Evenmin uit de „Carte de la Guyane française", dressée par Maurice Guffroy. (Chargé de Missions). Paris. (Z. j. maar na 1901).

Beide rivieren ontspringen in het Toemoek Hoemak-gebergte en beider loop past bij de algemeene richting van de MarowijneLawa.

Op de kaart bij het hiervoren genoemde artikel van Vidal is de Marowijne-kreek (die niet is opgenomen door de gemengde commissie) voor het grootste deel gestippeld. Het is niet duidelijk

$\left.{ }^{1}\right)$ Vidal, president van de Fransche afdeeling der gemengde commissie, maakt in zijn artikel „Voyage d'exploration dans le haut $M a$ roni", in de "Revue Maritime Coloniale", deuxième édition, Paris 1882, blz. 39 de opmerking:

„La langue de tous les nègres du Maroni est le négre créole de Surinam".

2) Crevaux schrijft n.1.: „2 Novembre. A quatre heures nous rencontrons des roches schisteuses que les Ouayanas appellent panakiri tepou (roches des Hollandais), parce qu'elles sont allignées comme les soldats de Suriname qui sont venus jadis faire la guerre dans le Maroni". 
waarom niet de geheele rivier, die als veel kleiner dan de Litani wordt afgebeeld, gestippeld is.

De „Carte d'ensemble du fleuve Maroni” par M. M. Ricour, Capitaine d'Infanterie de Marine et E. Burvingt, Sergent d'Infanterie de Marine, Paris 1892, beeldt de Litani af als een grootere rivier dan de Marowijne kreek, maar de richting van deze kreek past even goed als die van de Litani bij de algemeene richting van de Lawa.

De uit 40 kaarten bestaande atlas „Fleuves de l'Amérique du Sud", in 1883 door het Aardrijkskundig Genootschap te Parijs uitgegeven uit de nalatenschap van Crevaux, heb ik niet kunnen raadplegen ${ }^{1}$ )

Coudreau vertelt in zijn hiervoren genoemd boek dat de Boninegers in de Marowijne kreek van 1790-1815 acht dorpen hebben gehad ${ }^{2}$ ).

„Au dégrad de chacun de ces anciens villages, on retrouve les manguiers et les aouaras que les Bonis plantaient toujours autour de leurs villages dans toutes leurs migrations. (blz. 247).

„Un jour, l'officier hollandais, qui commandait la troupe hollandoyouca risqua une reconnaissance dans le Marouini, jusqu'à l'endroit appelé depuis par les Roucouyennes Panakiri Icholi (le saut des Hollandais), et, par les Bonis, Baca Campou (le Campement du Blanc), à une heure en aval du confluent du Ouanapi".....

„Et, avant de faire volte-face, l'officier laissa, sur une roche du saut, une inscription qui était au fond de l'eau quand je passai à Baca Campou'. (blz. 251).

Toen de strijd ten einde was zakten de Bonis de Marowijnekreek af en vestigden zich in de Lawa, waar zij door het Surinaamsche Gouvernement werden geplaatst onder het toezicht van den Granman der Aucaners, welk toezicht steeds door de Bonis is erkend totdat het Surinaamsche Bestuur in 1860 daar-

1) Hier zij nog vermeld een merkwaardige opvatting van een schrijver in "L'Illustration" van 13 Juni 1891, blz. 518, dus kort na de arbitrale uitspraak:

„Le triangle compris entre les deux affluents du Maroni [Lawa en Tapanahoni] appartient donc aujourd'hui sans contestation à la Hollande et la frontière définitive suit depuis la mer le cours du Maroni jusqu' au territoire des Poligoudoux. Là elle abandonne le Tapanahoni, désormais en pays hollandais, pour descendre [?] avec l'Aoua d'abord, l'Araoua ensuite, jusqu'à la source de ces deux affluents dans les monts Tumuc-Humac". De Araoua ontspringt niet in het genoemde gebergte.

2) Op blz. 245 spreekt hij van „une rivière de l'importance du Marouini, qui a plus de 250 kilomètres". 
aan een einde maakte. (Zie J. Wolbers „Geschiedenis van Suriname", Amsterdam 1861, blz. 758-761).

In de Memorie van Toelichting, behoorende bij het ontwerp van wet tot goedkeuring van het den 30sten September 1915 te Parijs tusschen Nederland en Frankrijk gesloten verdrag, strekkende tot regeling van de grens tusschen Suriname en Fransch Guyana over een gedeelte van de Marowijnerivier, welk ontwerp op 3 Maart 1916 aan de Tweede Kamer werd aangeboden (Gedrukte stukken 1915-1916-327 no. 3), schreven de Ministers Loudon en Pleyte:

„Reeds sinds geruimen tijd wordt zoowel door de Nederlandsche als door de Fransche Regeering als vaststaande aangenomen, dat de grens tusschen Suriname en Fransch Guyana gevormd wordt door de Marowijnerivier.

De grens was intusschen niet nader aangeduid, terwijl aanvankelijk alleen de benedenloop der rivier bekend was.

In 1861 verkende een gemengde Nederlandsch-Fransche commissie de rivier, zich stroomopwaarts begevend.

Zijkwam na een zeer nauwkeurig onderzoek daar, waar de Marowijne ontstaat uit de samenvloeiing van de Lawa en de Tapanahoni, tot de slotsom, dat de Lawa de hoofdrivier is; meer stroomopwaarts waar de Lawa op haar beurt ontstaat door de samenvloeiing van de Litani en de Marowinikreek, stempelde zij de Litani tot hoofdrivier.

De eerstgemelde conclusie werd door een arbitrale uitspraak van $Z$. M. den Czaar van Rusland van 13/25 Mei 1891 bevestigd.

Wat de tweede conclusie betreft, kan worden vermeld, dat latere onderzoekingen twijfel aan de juistheid daarvan hebben doen rijzen. Intusschen was de vraag of de Litani of de Marowijne kreek als hoofdrivier is te beschouwen, toenmaals niet het onderwerp van gedachtenwisseling tusschen de Nederlandsche en de Fransche Regeering, en dientengevolge is deze vraag ook niet onderworpen geweest aan de beslissing van den Hoogen scheidsrechter".

In verband met de overweging in de arbitrale uitspraak „qu'il est-admis sans conteste par les deux pays interessés que le fleuve Maroni, à partir de sa source, doit servir de limite entre leurs colonies respectives", rijst m.i. de vraag of de arbiter ook de opvatting deelde, in de door mij gecursiveerde woorden tot uiting gebracht. Immers eindigt de Marowijne, die „à partir de sa source" de grens moet zijn, niet bij de samenvloeiing van Litani en Marowijne-kreek.

Is het niet opmerkelijk dat de arbiter - die, vóór hij zich bereid verklaarde aan het hem gedane verzoek te voldoen, de bevoegdheid eischte om op het betwiste gebied een grens te maken, dus zich niet te houden aan historische of aardrijkskundige gron- 
den - niet heeft gevraagd of het de bedoeling was dat de beslissing zich niet over de geheele Marowijne moest uitstrekken?

Het wil mij voorkomen dat in de laatste alinea van de aangehaalde Memorie van Toelichting niet had moeten staan ,als hoofdrivier", maar "als grens". Immers heeft de Czaar zijne beslissing gegrond zoowel op historische als op aardrijkskundige gronden ${ }^{1}$ ).

Hoe meer men de arbitrale beslissing bekijkt hoe meer zij gaat gelijken op een orakel van Delphi. Terecht kon Coudreau zeggen dat er iets „vague et incomplet” was in den tekst van de „jugement arbitral".

Hoe zou de beslissing zijn geweest indien de scheidsrechter zich ook had moeten uitspreken over het verdere deel van de grens?

Natuurlijk is het antwoord op deze vraag niet te geven. Een poging daartoe heeft slechts akademische waarde.

Als hiervoren gezegd heeft de scheidsrechter op den voorgrond gesteld de overweging, dat in het betwiste gebied negers hebben gewoond „dépendant médiatement ou immédiatement de la domination Hollandaise".

Dit nu is ook het geval geweest in de Marowijnekreek. Op dezen grond zou dus deze rivier als de grens zijn aangewezen. Maar de gemengde commissie heeft de Litani als de hoofdrivier aangenomen.

De beide overwegingen zouden dus - anders dan bij de Lawa - met elkaar in botsing komen.

Is het nu gewaagd aan te nemen, dat de arbiter - overwegende dat de gemengde commissie de Marowijne kreek niet heeft opgenomen, dat het verschil in grootte tusschen Litani en Marowijnekreek waarschijnlijk niet belangrijk is en voorts dat deze kreek bij de daar gewoond hebbende Indianen en Negers denzelfden naam

$\left.{ }^{1}\right)$ In de Memorie van Antwoord op het Voorloopig Verslag der Tweede Kamer betreffende de „Goedkeuring van de op 28 April 1890 te Parijs uitgewisselde verklaring aangaande de bevoegdheid van den scheidsrechter in het aanhangig geschil betreffende de grensscheiding tusschen Suriname en Fransch Guyana" (Bijlagen 1889-90, 155, 6) kan men het volgende lezen:

„De regeering heeft in het Voorloopig Verslag met voldoening de bevestiging gevonden van de steeds door haar volgehouden meening, dat op geschied-, en aardrijkskundige gronden de Lawa als de bovenloop der Marowijne moet worden beschouwd".

De onjuiste gedachtengang, die in de door mij gecursiveerde woorden schuilt is in latere regeeringsverklaringen over een andere Surinaamsche grenskwestie meermalen opgedoken. 
droeg als de hoofdrivier - de historische overweging beslissend zou hebben geacht?

Het is te betreuren dat de betrokken Regeeringen niet om nader uitleg hebben verzocht, toen het nog mogelijk was dien te verkrijgen.

In de Memorie van Antwoord op het Voorloopig Verslag der Tweede Kamer nopens bovengenoemd wetsontwerp gaven de Ministers

„gaarne de verzekering er naar te zullen streven dat eene regeling ook omtrent den verderen loop der grens zoo spoedig mogelijk tot stand kome".

Sedert zijn 14 jaren verloopen en nog ligt die regeling in het verschiet.

Maar door het initiatief van Brazilië om de grenzen af te bakenen moeten de Fransche en de Nederlandsche Regeering tot overeenstemming komen. Het drielanden-punt moet worden vastgesteld vóór men aan de afbakening tusschen de bronnen van Litani en Marowijnekreek kan beginnen.

Het is te verwachten dat de Fransche Regeering de Litani als grens zal willen aangewezen zien. Zij vergete niet dat de Fransche Regeering eenmaal alle waarde ontzegde aan de verrichtingen der gemengde commissie. (Zie blz. 365 van de voortreffelijke studie van wijlen J. T. Niermeyer „De Surinaamsche grensquaestie”, in „Vragen des tijds", 1891, 2e deel). Wij van onzen kant hebben het recht ons te houden aan de door den arbiter in het geval van de Lawa vooropgestelde historische overweging en dus de Marowijnekreek als de grens te beschouwen, ook al zou ze blijken niet de hoofdrivier te zijn.

Wellicht komt men het spoedigst tot een oplossing door een nieuwe arbitrage.

Den Haag, 3 October 1930.

Naschrift.

In het op 21 October 1930 vastgestelde Voorloopig Verslag der Tweede Kamer betreffende de begrooting van Buitenlandsche Zaken luidt § 5. Grenzen van Suriname:

„Gevraagd werd, of nu de grensregeling tusschen Suriname en Braziliē vrijwel haar beslag heeft gekregen, met Engeland besprekingen gaande zijn of zullen worden geopend ter bepaling van de Westgrens van Suriname", 
De Oostgrens is hierbij over het hoofd gezien.

De Memorie van Antwoord van den Minister van Koloniën betreffende het hiervoren genoemde wetsontwerp tot wijziging en verhooging van het XIde hoofdstuk der Rijksbegrooting voor 1930 is bij brief van 29 October 1930 ingezonden:

„Het zou den ondergeteekende tot groote voldoening strekken, indien het thans met de betrokken Regeeringen geopend overleg nopens eene definitieve regeling van de grenzen tusschen Suriname en de Britsche en Fransche gedeelten van Guyana met goeden uitslag zou worden bekroond.

Het denkbeeld om te zijner tijd bij de werkzaamheden voor grensafbakening mede gebruik te maken van vliegtuigen heeft reeds de aandacht der Regeering".

Het antwoord van den Minister van Buitenlandsche Zaken in zijne Memorie van Antwoord, ingezonden bij brief van $5 / 8$ November 1930, luidt:

„Sedert eenigen tijd is met Engeland eene gedachtewisseling gaande tot regeling van de grensscheiding tusschen Suriname en Britsch-Guyana."

Het op 13 November vastgestelde Voorloopig Verslag der Tweede Kamer nopens de Rijksbegrooting voor het dienstjaar 1931, $\mathrm{XI}{ }^{\text {de }}$ hoofdstuk, schrijft over de grensafbakening:

,Inlichtingen werden verzocht omtrent de werkzaamheden, betrekking hebbende op de afbakening van de zuidgrens van Suriname. Zullen, vroeg men voorts, ook de oostelijke en de westelijke grenzen van het gewest nader worden afgebakend?"

Ik wil dit artikel niet eindigen, zonder de aandacht te vestigen op de juist verschenen ,,Kaart van Suriname”, in 16 bladen, schaal 1 op 200,000, samengesteld in de projectie van Mercator, door L. A. Bakhuis en W. de Quant.

De New River en de Koeroeni bekijkende kwam de vraag bij mij op:

Zou Schomburgk, als hij niet door gebrek aan levensmiddelen gedwongen was vliegensvlug de rivier af te zakken maar de New River had kunnen opnemen, een oogenblik geaarzeld hebben de New River als de voortzetting van de Corantijn en dus als de grens aan te wijzen? 